\title{
Analysis Of The Factors That Influence Islamic Bank Capital Buffers In Indonesia
}

\author{
Ulis Fajar Choirotun Hisan ${ }^{1, a^{*}}$, Dina Fitrisia Septiarini ${ }^{1, b}$, Dian Filianti ${ }^{1, c}$ \\ ${ }^{1}$ Islamic Economics, Faculty of Economics and Business, Universitas Airlangga \\ Jl. Airlangga No. 4, Surabaya, East Java, Indonesia \\ e-mail: ${ }^{a^{*}}$ ukis.fajar.choirotun-2016@feb.unair.ac.id, ${ }^{\mathrm{b}}$ dina.fitrisia@feb.unair.ac.id, \\ c dianfilianti@feb.unair.ac.id \\ * Corresponding Author
}

\begin{abstract}
Banks are trust institutions. An appropriate tool in sustaining trust is the capital adequacy of the bank (capital buffer). This study aims to analyze the effect of financing risk (NPF), operational risk (BOPO), market risk (NI), Third Party Funds (DPK), GDP Growth (GDPG) and inflation on BUS capital buffers in Indonesia during the 2014-2018 period. This study uses panel data regression method with a sample of 12 BUS based on purposive sampling technique. BOPO, $D P K, G D P G$, and INF were found to have a significant effect on BUFF, where BOPO, DPK, and INF had a negative effect, while GDPG was positive. So operational risk, third party funds, GDP Growth, and inflation can be said to be determinants of BUS capital buffers in Indonesia in the 2014-2018 period. Financing risk (NPF) and market risk (NI) have no significant effect on BUS capital buffer in the study period. Regarding basel III implementation, operational risk is a significant determinant of capital buffer, and capital buffer is found to be procyclical to the Indonesian economy. Future studies can include more risk measurement variables and other macroeconomic variable
\end{abstract}

Keywords: Capital Buffer, Macroeconomic Condition, Risk Profile

Article History: Received: September, 42020 Revised: September, 152020 Accepted: October, 92020

How to cite: Hisan, U. F. C., Septiarini, D. F., \& Filianti, D. (2020). Analysis of The Factors That Influence Islamic Capital Buffers In Indonesia. Akrual: Jurnal Akuntansi, 12(1):80-93 DOI: https://doi.org/10.26740/jaj.v12n1.p80-93

\section{INTRODUCTION}

Banks are trust institutions. The appropriate tool in sustaining trust is the adequacy of capital banks (capital buffer). Capital must be used to maintain the possibility of the risk of loss of investment in assets, especially those from the community (Muhammad, 2005). The function of capital according to Johnson \& Johnson (1985), one of which is a buffer to absorb operational losses and other losses. UU no. 21 of 2008 article 38 requires Islamic banks to apply risk management, the principle of getting to know customers, and customer protection. Therefore, effective risk management is needed related to the implementation of Islamic bank activities as an institution of trust and intermediation. In this case, the bank can provide a capital buffer or capital buffer, which is measured through the difference between the CAR and government regulations regarding the minimum capital that must be owned by banking institutions which is equal to $8 \%$ (OJK, 2019). 
The capital of many banking institutions is faced with microprudential aspects such as financing risk, market risk, operational risk, and third party funds. These microprudential aspects can be measured with financial ratios such as Non-Performing Financing (NPF) to measure financing or credit risk (Atici \& Gursoy, 2013; Bayuseno \& Chabahib, 2014; Daher et al., 2015; Ghosh, 2017; Jokipii \& Milne, 2008; Noreen et al., 2016; Sutrisno, 2018). Operating Expenses Operating Income (BOPO) to measure operational risk (Agustuty \& Ruslan, 2019; Sutrisno, 2018), Net Rewards (NI) to measure market risk (Prasetyoko and Seodarmono, 2015 ; Sutrisno, 2018). And third party funds or deposits (Xu et al., 2015; Zhu \& Chen, 2016).

In addition to the microprudential aspect, the macroprudential aspect also influences the capital buffer. Gross Domestic Product Growth is used to see the effect of the business cycle or the level of procyclicality on capital buffers (Ayuso et al., 2004; Jokipii \& Milne, 2008; Noreen et al., 2016). Besides, Williams (2011), who examined the impact of macroeconomic variables on capital adequacy on banks in Nigeria during the 1980-2008 period, found that money supply, real exchange rates, domestic interest rates, inflation, and political instability have a relationship to capital adequacy in Nigeria. Awojobi (2011) also states that the efficiency of capital adequacy in banks in Nigeria is not only influenced by bank-specific factors but also influenced by macroeconomic variables. Based on the background above, the authors wish to examine the influence of fundamental factors and macroeconomic conditions on Islamic bank capital buffers.

Capital Adequacy serves as a protective net against the risks that may occur and are faced by banks. Quoting from Van Greuning \& Iqbal (2007) the main purpose of capital is to provide stability and absorb losses, to protect customers and depositors in the event of a liquidation. The function of capital is to reduce risk (Koch, T. W., \& MacDonald, 2003). This is based on three points, which are the cushion for banks to absorb losses and remain solvent, open access to financial markets, and limit growth and risk-taking. One of the functions of capital according to Johnson \& Johnson (1985) is as a buffer to absorb operational losses and other losses. Regulations related to capital adequacy of financial institutions, especially banks, are regulated in Basel standards.

Basel standard is a standard issued by the Basel Committee on Banking Supervision (BCBS) to make regulations for banking institutions in the international sphere. Quoted from the Financial Services Authority, since 2010, Basel III is the latest regulation in response to the financial crisis in 2008. The Basel III framework, relating to global regulations for banks and a stronger banking system, is to strengthen the quality and quantity of capital (OJK, 2019). Strengthening banking capital is done by: (1) Correctly classifying financial instruments classified as capital, namely Common Equity Tier (CET) 1, Additional Tier (AT) 1, and Tier 2; (2) Adding buffer obligations consisting of Conservation Buffer, Countercyclical Capital Buffer, G-SIB, and D-SIB Capital Charge; (3) add the Capital Loss Absorption at the Point of Non-Viability (PONV) feature (OJK, 2014). In December 2006, for the first time, the IFSB issued a capital adequacy standard 
for institutions offering Islamic financial services (except insurance). As with conventional financial institutions, the minimum capital requirement for Islamic financial institutions is $8 \%$. Based on a series of problem descriptions above, this study is interested in researching on factors that influence islamic banks capital buffer in Indonesia from 2014-2018.

\section{RESEARCH METHOD}

Research Approach

This research uses a quantitative approach with panel data regression method.

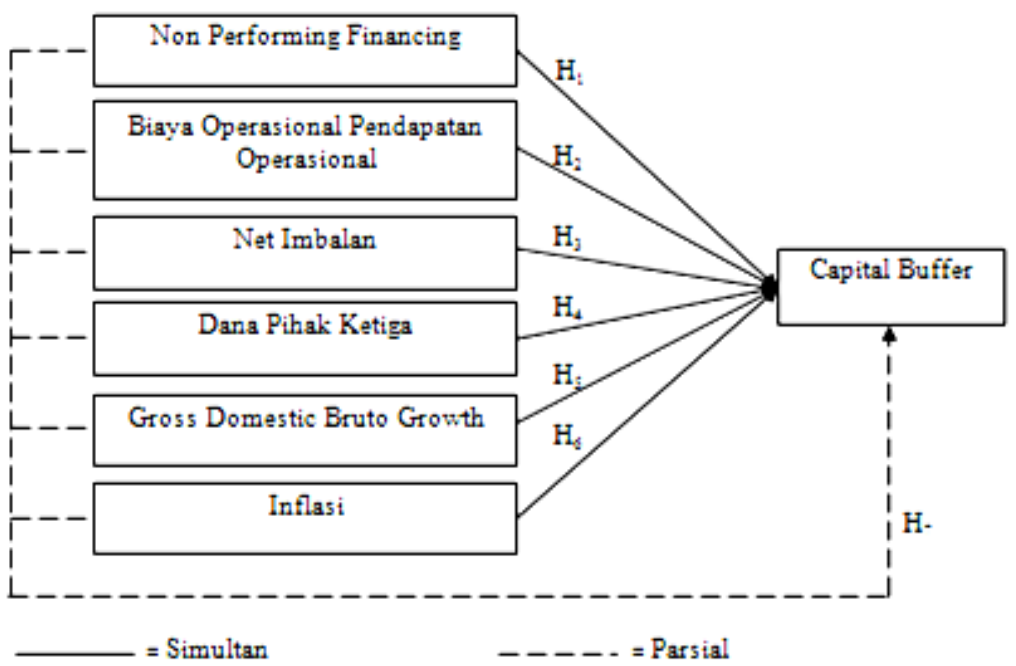

Figure 1. Empirical Model

Source: processed data

The data used are secondary data from the official website of the Central Statistics Agency (BPS), the Financial Services Authority (OJK), Bank Indonesia (BI), and BUS annual report. The population in this study was 14 BUS in Indonesia registered and supervised by the OJK. By using a purposive sampling technique, then obtained many 12 BUS business samples in Indonesia.

\section{Variables}

Financing risk (credit risk) is the risk that occurs due to the party who proposed financing failed to meet their obligations (Umam, 2013). Financing risk can be represented by nonperforming financing (NPF) in Islamic banks. This research uses NPF Net which considers allowance for earning assets losses (PPAP) in its calculations. NPF ratio of Islamic banks can be calculated by the formula SEOJK (2015):

$N P F=\frac{\text { Non-performing Loan-PPAP Non-performing }}{\text { Total Funding }} \times 100 \%$

Van Greuning \& Iqbal (2007) define operational risk as to the risk of loss arising from limitations or failures of internal processes, related to systems, technology, people, analytical models, and external risks. Operational risk in this study is measured using the 
ratio of Operational Costs to Operating Income (BOPO), with the calculation formula based on SEOJK (2015) as follows:

BOPO $=\frac{\text { Total Operating Costs }}{\text { Total Operating Income }} \times 100 \%$

Market risk can be defined as the risk that a bank experiences possible losses caused by fluctuating movements in market prices (Van Greuning \& Iqbal, 2007). If conventional banks have a Net Interest Margin (NIM) ratio, then Islamic banks have a Net Return ratio (NI) which also reflects market risk with the same soundness level. Based on SEOJK (2015) NI and NIM of Islamic banks can be calculated using the formula:

Disbursement Revenue after Profit Sharing

$N I=\frac{(\text { Rewards dan Bonuses })}{\text { Average Total Earning Assets }} \times 100 \%$

$N I M=\frac{\text { Net Revenue }}{\text { Average Earning Assets }} \times 100 \%$

Funds are cash received and managed by the bank in cash or other current assets. The money does not only come from the owners, but also from people who entrust their money as a deposit or the inclusion of other parties' funds which will then be taken back at a certain time, either at once or gradually (Muhammad, 2005). In general, third-party funds are received by banks in the form of demand deposits, savings, and deposits which can be written as follows:

DPK = Current Account + Savings + Deposit

Mankiw et al. (2014) explains that GDP is calculated in a country in a certain period through the market value of all goods and services. The movement of the business cycle can be used to see the procyclical behavior of financial institutions that can be measured through the percentage of GDP growth (Ayuso et al., 2004; Jokipii \& Milne, 2008; Noreen et al., 2016). GDP growth shows the difference between this year's GDP and the previous year.

Rahardja and Manurung (quoted from Huda, 2008) suggest that inflation is a symptom of rising prices of goods and/or services that are general and continuous. Inflation can measured by consumen price index.

\section{Analysis Techniques}

The first step is to do panel data regression which is a combination of cross-section and time-series data. Next will be chosen the best regression model between Ordinary Least Square (OLS), Fixed Effect Model (FEM), and Random Effect Model (REM) through the chow test and the Hausman test. The chow test is used to choose between OLS and FEM models. If the results show FEM selected, it will be followed by a thirsty test to choose between FEM and REM. In this study, the Generalized Least Square (GLS) test is used to test heteroscedasticity and autocorrelation between variables. Besides, partial and 
simultaneous tests were carried out using the t-test and the F test, as well as the coefficient of determination test (R2) to determine the magnitude of the influence of the independent variable on the dependent.

\section{Regression Model}

The regression model used to determine the determinant of BUS capital buffers is as follows:

Yit $=\beta i+\beta 1 N P F i t+\beta 2$ BOPOit $+\beta 3$ NIt $+\beta 4 D P$ Kit $+\beta 5$ GDPGit $+\beta 6 I N F i t+e$ (1)

Where $\mathrm{i}$ is a symbol for cross-section, $\mathrm{t}$ for time series, Yit as the $\mathrm{i}$ bank's capital buffer and t-time, $\beta \mathrm{i}$ as a constant coefficient, NPF or Non Performing Financing as financing risk, NI (Net Rewards) as market risk, DPK as third party funds, GDPG as GDP Growth, INF as a symbol of inflation, $\beta 1-\beta 6$ as a regression coefficient and symbol e for the error variable.

\section{RESULTS AND DISCUSSION}

Selection of Estimated Models

Table 1. Chow Test Results

\begin{tabular}{|c|c|c|c|}
\hline & \multicolumn{3}{|c|}{ 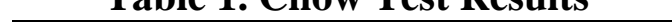 } \\
\hline & Effects Test & Prob & Description \\
\hline & $\begin{array}{l}\text { Cross-section } \\
\mathrm{F}\end{array}$ & 0,00 & $\begin{array}{ll}\mathrm{H} 0 & \text { is } \\
\text { rejected }\end{array}$ \\
\hline
\end{tabular}

The chow test results show a probability of 0.00 which means that the Fixed Effect Model (FEM) is chosen as an appropriate estimation model compared to Ordinary Least Square (OLS).

Table 2. Hausman Test Results

\begin{tabular}{lll}
\hline Effects Test & Prob & Description \\
\hline Cross-section F & $-0,31$ & H0 is rejected \\
\hline
\end{tabular}

Source: Stata13, data processed

After conducting the chow test, the next step is to perform the hausman test. The probability value on the Hausman test is -0.31 . This negative value indicates if the null hypothesis cannot be rejected, so that $\mathrm{HO}$ is accepted and REM is chosen as the most appropriate model to use.

Based on the results of panel data regression using stata13, simultaneous financing risk, operational risk, market risk, DPK, GDPG, and inflation affect the BUS capital buffer. The F test results in table 3 show an F value of 0.0000 which is smaller than $\alpha=$ 0.05 so that $\mathrm{HO}$ is rejected. Based on the coefficient of determination or r-square shown by the same table with a value of 0.7705 or $77 \%$, shows that the independent variables used to explain the effect on BUS capital buffers in Indonesia from 2014 to 2018 of $77 \%$. While the remaining $23 \%$ is explained by variables outside this study. 
Hisan, Septiarini, \&Filianti, Analysis of the factors that influence.....

Panel Data Regression Results

Table 3. Panel Data Regression Results - Random Effect Model

\begin{tabular}{ccccc}
\hline Var & Koef & Std. Error & z-stat & Prob. \\
\hline C & 60,96441 & 37,84615 & 1,61 & 0,107 \\
NPF & $-0,086809$ & 0,745398 & $-0,12$ & 0,907 \\
BOPO & $-0,108197$ & 0,033010 & $-3,28$ & 0,001 \\
NI & 0,169520 & 0,323150 & 0,52 & 0,600 \\
DPK & $-9,94755$ & 0,667518 & $-14,9$ & 0,000 \\
GDPG & 24,5302 & 6,689525 & 3,67 & 0,000 \\
INF & $-0,578920$ & 0,299044 & $-1,94$ & 0,053 \\
C & 60,9644 & 37,8461 & 1,61 & 0,107 \\
R $^{2}$ & \multicolumn{5}{c}{0,7705} \\
Obs & \multicolumn{5}{c}{0,0000} & \\
Prob>F & \multicolumn{5}{c}{} \\
\hline
\end{tabular}

Source: Stata13, data processed

\section{Statistic test}

Normality test functions to test whether the variables used both dependent and independent are normally distributed. A normality test can be done using residual charts from research. Based on the graph of normality test results, the residuals of the results of the study show a distribution that is close to normal. This can be seen through the scattered dots following the lines in figure 2.

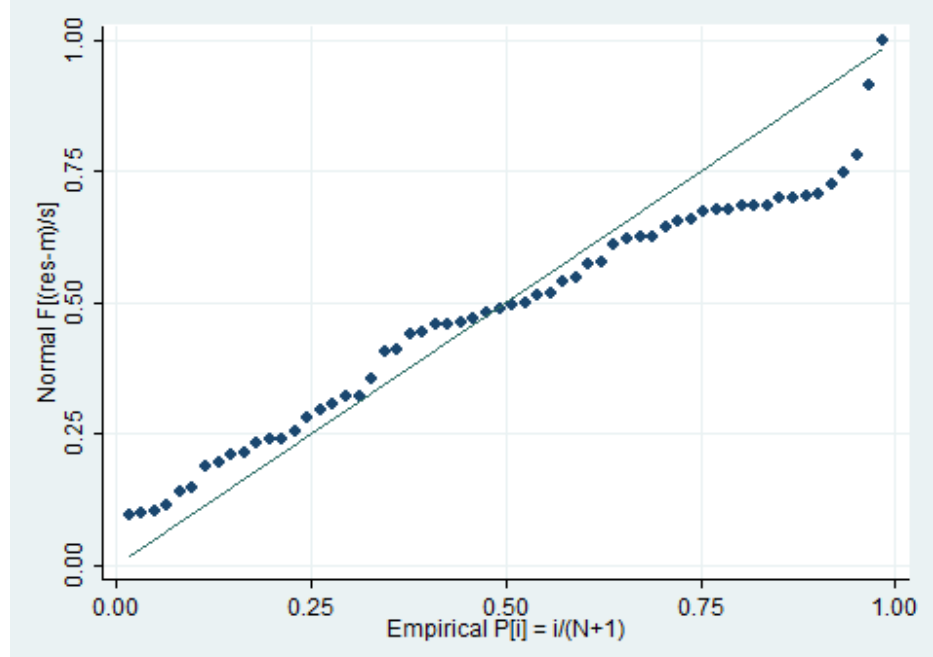

Figure 2. Normality Test Results

Source: Stata 13

Multicollinearity test serves to test whether there is a correlation between independent variables in the regression model. The multicollinearity test is based on the assumption that if the VIF value $<10$, then there is no multicollinearity between independent variables and vice versa. Overall independent variables used in this study do 
not indicate multicollinearity problems as indicated by the average value of the six variables vif of 1.47 which can be seen in Figure 3.

\begin{tabular}{rlccc} 
Variable & VIF & $\begin{array}{c}\text { SQRT } \\
\text { VIF }\end{array}$ & $\begin{array}{c}\text { R- } \\
\text { Tolerance }\end{array}$ & Squared \\
\hline NPF & 1.70 & 1.31 & 0.5868 & 0.4132 \\
BOPO & 1.94 & 1.39 & 0.5154 & 0.4846 \\
NI & 1.35 & 1.16 & 0.7426 & 0.2574 \\
1n_DPK & 1.71 & 1.31 & 0.5838 & 0.4162 \\
GDPG & 1.08 & 1.04 & 0.9301 & 0.0699 \\
INF & 1.05 & 1.02 & 0.9565 & 0.0435 \\
\hline Mean VIF & 1.47 & & &
\end{tabular}

Source: Stata 13

Figure 3. Multicollinearity Test Results

In the Random Effect Model, heterokedastity test and autokoleration test can be seen through the General Least Square test in Figure 3. In the GLS test found the same variance from the residuals of one observation to another observation or called homokedastisitas. In addition, the GLS test also shows that there is no relationship or correlation between one variable itself, on different observations.

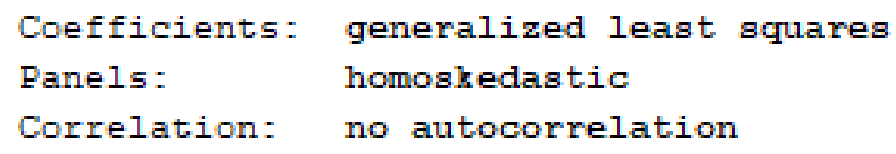

Figure 4. GLS Test Results

\section{Selection of Estimated Models}

\begin{tabular}{lll}
\multicolumn{3}{c}{ Tabel 1. Hasil Uji Chow } \\
\hline Effects Test & Prob & Description \\
Cross-section & 0,00 & H0 \\
$F$ & & rejected \\
\hline
\end{tabular}

Source: Stata13, data processed

The chow test results show a probability of 0.00 which means that the Fixed Effect Model (FEM) is chosen as an appropriate estimation model compared to Ordinary Least Square (OLS).

Source: Stata13, data processed

Table 2. Hausman Test Results

\begin{tabular}{lll}
\hline Effects Test & Prob & Description \\
Cross-section F & $-0,31$ & H0 is rejected \\
\hline
\end{tabular}

After conducting the chow test, the next step is to perform the hausman test. The probability value on the Hausman test is -0.31 . This negative value indicates if the null 
Hisan, Septiarini, \&Filianti, Analysis of the factors that influence.....

hypothesis cannot be rejected, so that $\mathrm{H} 0$ is accepted and REM is chosen as the most appropriate model to use.

Panel Data Regression Results

\begin{tabular}{ccccc}
\multicolumn{5}{c}{ Table 3. Panel Data Regression Results - Random Effect Model } \\
\hline Var & Koef & Std. Error & z-stat & Prob. \\
\hline C & 60,96441 & 37,84615 & 1,61 & 0,107 \\
NPF & $-0,086809$ & 0,745398 & $-0,12$ & 0,907 \\
BOPO & $-0,108197$ & 0,033010 & $-3,28$ & 0,001 \\
NI & 0,169520 & 0,323150 & 0,52 & 0,600 \\
DPK & $-9,94755$ & 0,667518 & $-14,9$ & 0,000 \\
GDPG & 24,5302 & 6,689525 & 3,67 & 0,000 \\
INF & $-0,578920$ & 0,299044 & $-1,94$ & 0,053 \\
C & 60,9644 & 37,8461 & 1,61 & 0,107 \\
R & \multicolumn{5}{c}{0,7705} \\
Obs & 600 & \\
Prob>F & \multicolumn{5}{c}{0,0000} \\
\hline
\end{tabular}

Source: Stata13, data processed

Based on the results of panel data regression using stata13, simultaneous financing risk, operational risk, market risk, DPK, GDPG, and inflation affect the BUS capital buffer. The F test results in table 3 show an $F$ value of 0.0000 which is smaller than $\alpha=$ 0.05 so that $\mathrm{HO}$ is rejected. Based on the coefficient of determination or r-square shown by the same table with a value of 0.7705 or $77 \%$, shows that the independent variables used to explain the effect on BUS capital buffers in Indonesia from 2014 to 2018 of $77 \%$. While the remaining $23 \%$ is explained by variables outside this study. 


\section{Statistic test}

Normality test functions to test whether the variables used both dependent and independent are normally distributed. A normality test can be done using residual charts from research. Based on the graph of normality test results, the residuals of the results of the study show a distribution that is close to normal. This can be seen through the scattered dots following the lines in figure 2 .

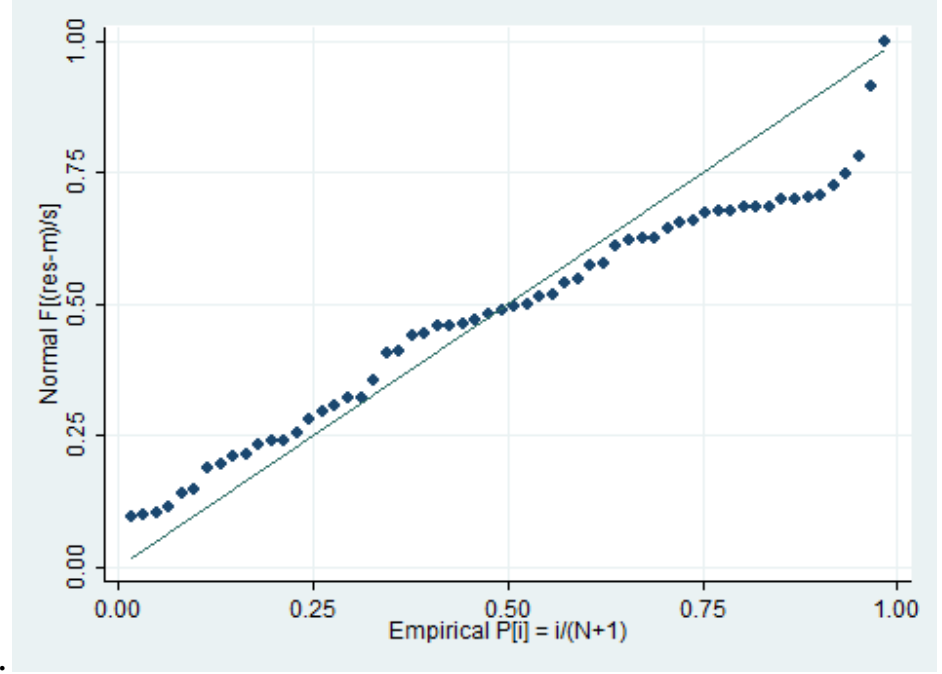

Source: Stata 13

Figure 2. Normality Test Results

Multicollinearity test serves to test whether there is a correlation between independent variables in the regression model. The multicollinearity test is based on the assumption that if the VIF value $<10$, then there is no multicollinearity between independent variables and vice versa. Overall independent variables used in this study do not indicate multicollinearity problems as indicated by the average value of the six variables vif of 1.47 which can be seen in Figure 3.

\begin{tabular}{|c|c|c|c|c|}
\hline Variable & VIF & $\begin{array}{l}\text { SQRT } \\
\text { VIF }\end{array}$ & Tolerance & $\begin{array}{c}\text { R- } \\
\text { Squared }\end{array}$ \\
\hline NPF & 1.70 & 1.31 & 0.5868 & 0.4132 \\
\hline BOPO & 1.94 & 1.39 & 0.5154 & 0.4846 \\
\hline NI & 1.35 & 1.16 & 0.7426 & 0.2574 \\
\hline ln_DPK & 1.71 & 1.31 & 0.5838 & 0.4162 \\
\hline GDPG & 1.08 & 1.04 & 0.9301 & 0.0699 \\
\hline INF & 1.05 & 1.02 & 0.9565 & 0.0435 \\
\hline
\end{tabular}

Source: Stata 13

Figure 3. Multicollinearity Test Results

In the Random Effect Model, heterokedastity test and autokoleration test can be seen through the General Least Square test in Figure 3. In the GLS test found the same variance 
from the residuals of one observation to another observation or called homokedastisitas. In addition, the GLS test also shows that there is no relationship or correlation between one variable itself, on different observations.

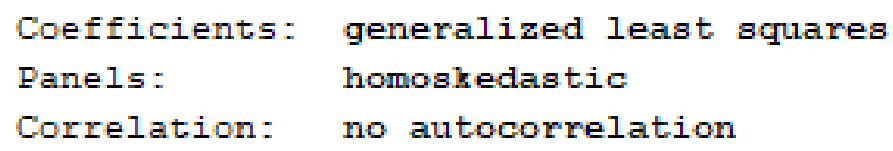

Figure 4. GLS Test Results

Source: Stata 13

\section{Robustness Test}

The validity test or robustness test in this study was conducted twice, by conducting a panel data regression test using different amounts and variables. The first robustness test is done by eliminating two insignificant variables, so we get 4 variables with statistically significant results. The second robustness test is done by eliminating the macroeconomic variables used and adding other microeconomic variables, namely ROA and GWM, to obtain a total of 6 microeconomic variables that together affect BUFF. Both robustness tests use the same model as the main model of this study, the Random Effect Model (REM).

The first robustness test results show the consistency of the variables used namely BOPO, DPK, GDGP, and INF. Where the four variables still have a significant effect after two variables that are not significantly removed (NPF and NI). Whereas the second robustness test implies that the BUS capital buffer in Indonesia during the 2014-2018 period together was more influenced by microeconomic variables. This can be seen through the r-square value which has a slightly higher value which is $78 \%$ without macroeconomic variables.

\section{Discussion}

Financing risk as measured by NPF has no significant negative effect on Islamic bank capital buffer. Similar results were also found by Bayuseno \& Chabahib (2014) who also found an insignificant effect of NPL on capital buffers. Bayuseno \& Chabahib argued that these results indicate that commercial banks went public in Indonesia during the 20102013 period to adopt various policies. Some banks may increase their capital buffer with caution, while others may experience a decline in retained earnings due to rising NPLs, making it difficult for banks to increase their capital buffer or even use their capital buffer for operational activities. Although not significantly these results support Atici \& Gursoy (2013) and Ghosh (2017) who find a significant negative effect between NPLs and capital buffers, this shows that the higher the bank's risk preferences, the lower the level of the capital buffer it has. Gosh explained the negative relationship because Islamic banks are less at risk compared to conventional banks so that Islamic banks do not need to hold more capital reserves in their activities. 
This study found no significant effect between NPF and capital buffer. This can be caused by several possibilities, namely (1) The existence of moral hazard that can affect the repayment of financing provided by Islamic banks, so repayments tend to be unstable or insignificant, (2) Islamic banks may use collateral as the main alternative in covering risks financing rather than using a capital buffer so that the capital buffer is not directly exposed or affected by the NPF, and (3) Islamic banks may wait for a reaction from financing risks before deciding on the next steps to mitigate these risks, so it takes time for the NPF to affect the capital buffer.

The operational risk of Islamic banks is more significant compared to conventional banks, this is caused by Islamic bank agreements that are specific to the general environment (Van Greuning \& Iqbal, 2007). Therefore, Islamic banks must use the principle of prudence in managing operational risk to suppress more limited economic capital to manage its resources more efficiently, while providing convenience for stakeholders (Van Greuning \& Iqbal, 2007).

Market risk as measured by NI has no significant positive effect on BUS risk, similar results were also found by Mili et al. (2016). According to Mili et al. in his research related to CAR determinants in branch banks owned by foreign banks found a non-significant positive relationship between NIM and capital adequacy. Although found to be insignificant in line with these results, Sutrisno (2018) suggests that the higher the NIM will increase the capital buffer because banks can increase their profits efficiently which in turn will increase the capital buffer. The insignificant effect of market risk can also be explained through the pass-through nature of Islamic banks, which act as agents for depositors and investors. Islamic banks will distribute the profits and losses to each party. Besides, a means of risk-sharing, where Islamic banks with depositors and investors participate in risks borne by each other.

DPK has a significant negative effect on BUS capital buffer, each increase of one DPK unit will reduce the capital buffer by $9.95 \%$. This study supports the results of Daher et al. (2015) which found a significant negative effect of deposits on the capital buffer of state-owned Islamic banks. Daher explained that state-owned Islamic banks which tend to have larger deposits than private-owned Islamic banks are more risk-tolerant because they have a larger capital buffer. The results of this study are also consistent with the notion that banks with large sizes are considered as "too-big-to-fail" banks.

GDPG has a significant positive effect on BUS capital buffer, where each increase of one unit of GDPG will increase BUS capital buffer by 24.53\%. Carvallo et al. (2015) found a negative and positive relationship between GDPG and capital buffers in Latin American countries which indicated that in the general sample countries showed differences in cyclical behavior. A positive effect indicates that capital buffers behave procyclically, while negative influences indicate that capital buffers behave countercyclically. Noreen et al. (2016) also found significant positive results of GDPG with a capital buffer, which shows that the capital buffer moves positively with the 
economic cycle. A significant positive effect of GDPG shows that BUS capital buffer in Indonesia during the study period was procyclical. Where BUS will increase its capital buffer when the economy is good (boom period) to absorb losses during a crisis (boost period) or commonly called countercyclical capital buffer in regulation III.

Inflation (INF) has a significant negative effect on BUS capital buffer, each increase of one unit of the amount of INF will reduce BUS capital buffer by $0.58 \%$. The results of this study are in line with Bitar et al. (2018) which also found a significant negative effect on inflation and capital buffer, this indicates that an increase in inflation will reduce the capital buffer. The negative relationship between inflation and capital buffer in this study can be explained if the economy grows too fast or starts to show a sharp increase accompanied by rising inflation, where money supply tends to increase, then the monetary authority, in this case, Bank Indonesia through its monetary policy can carry out operations open market operations (open market operations), raising the minimum reserve requirement (reserve requirements), or raising interest rates (interest or discount rates) which will further slow down economic growth (Huda, 2008). With the contractive monetary policy implemented by Bank Indonesia, even though the Islamic bank does not use the interest system in its operations, it will still be affected by the macroeconomic policy, namely the withdrawal of money in Islamic banks. Money received by Islamic banks will decrease, which then reduces capital and capital buffers.

\section{CONCLUSION}

This study aims to determine the determinants of BUS capital buffer in Indonesia during 2014-2018. BOPO, DPK, GDPG, and INF have a significant effect on BUFF, so operational risk variables, third party funds, GDP Growth, and inflation can be said as determinants of BUS capital buffer in Indonesia during the 2014-2018 period. While financing risk (NPF) and market risk (NI) have no significant effect on BUS capital buffers (BUFF) in the study period. Regarding the implementation of Basel III, operational risk is a significant determinant of the capital buffer, and the capital buffer is positively related (procyclical) to the Indonesian business cycle.

\section{REFERENCES}

Agustuty, L., \& Ruslan, A. (2019). Determinan Capital Buffer Pada Industri Perbankan Di Indonesia. Movere Journal, 1(2), 164-174.

Atici, G., \& Gursoy, G. (2013). The determinants of capital buffer in the Turkish banking system. International Business Research Journal, 6(1), 224-234. doi:10.5539/ibr.v6n1p224

Awojobi, O. (2011). Analysing risk management in banks: Evidence of bank efficiency and macroeconomic impact. Journal of Money, Investment and Banking, 22.

Ayuso, J., Pérez, D., \& Saurina, J. (2004). Are capital buffers pro-cyclical? Journal of Financial Intermediation, 13(2), 249-264. doi:10.1016/s1042-9573(03)00044-5 
Bayuseno, V., \& Chabahib. (2014). Analysis of factors affecting banking capital buffer in Indonesia (Study of conventional banks going public in the 2014-2013 period). Diponegoro Journal of Management, 3(4), 1-13.

Bitar, M., Kabir Hassan, M., \& Hippler, W. J. (2018). The determinants of Islamic bank capital decisions. Emerging Markets Review, 35, 48-68. doi:10.1016/j.ememar.2017.12.002

Carvallo, O., Kasman, A., \& Kontbay-Busun, S. (2015). The Latin American bank capital buffers and business cycle: Are they pro-cyclical? Journal of International Financial Markets, Institutions and Money, 36, 148-160. doi:10.1016/j.intfin.2015.02.003

Daher, H., Masih, M., \& Ibrahim, M. (2015). The unique risk exposures of Islamic banks' capital buffers: A dynamic panel data analysis. Journal of International Financial Markets, Institutions and Money, 36, 36-52. doi:10.1016/j.intfin.2015.02.012

Ghosh, S. (2017). Capital buffers in Middle East and North Africa (MENA) banks: is market discipline important? International Journal of Islamic and Middle Eastern Finance and Management, 10(2), 208-228. doi:10.1108/imefm-08-2016-0101

Huda, N. et al. (2008). Islamic Macro Economy: Theoretical Approach. Kencana Prenada Media Group.

Johnson, F. P., \& Johnson, R. D. (1985). Commercial bank management. Dryden Pr.

Jokipii, T., \& Milne, A. (2008). The cyclical behaviour of European bank capital buffers. Journal of Banking \& Finance, 32(8), 1440-1451. doi:10.1016/j.jbankfin.2007.12.001

Koch, T. W., \& MacDonald, S. S. (2003). Bank management (Fifth Edit). South-Western Thomson.

Mankiw, N. G., Quah, E., \& Wilson, P. (2014). Pengantar Ekonomi Makro: Edisi Asia. Jakarta: Salemba Empat.

Mili, M., Sahut, J.M., Trimeche H., \& Teulon, F. (2016). Determinants of the capital adequacy ratio of foreign banks' subsidiaries: The role of interbank market and regulation. Research in International Business and Financ, 42, 442-453. http://dx.doi.org/doi:10.1016/j.ribaf.2016.02.002

Muhammad. (2005). Sharia bank management. UPP STIM YKPN.

Noreen, U., Alamdar, F., \& Tariq, T. (2016). Capital buffers and bank risk: Empirical study of adjustment of Pakistani banks. International Journal of Economics and Financial Issues, 6(4).

OJK. (2015). Surat Edaran Otoritas Jasa Keuangan No. 34/SEOJK.03/2015 tentang Perhitungan Aset Tertimbang Menurut Risiko untuk Risiko Kredit Menggunakan Metode Standar bagi Bank Umum Syariah.

OJK. (2015). Surat Edaran Otoritas Jasa Keuangan No. 35/SEOJK.03/2015 tentang Perhitungan Aset Tertimbang Menurut Risiko untuk Risiko Pasar Menggunakan Metode Standar bagi Bank Umum Syariah.

OJK. (2019). OJK Terapkan Perhitungan Risiko Pasar Basel III Terbaru. SP 02/DHMS/OJK/I/2019.

Prasetyantoko, A., dan Soedarmono, W. (2015). The determinants of capital buffer in Indonesian banking. Social Science Research Network, 370.

RI Law. (2008). Syariah banking. Jakarta: Law of the Republic of Indonesia. 
Hisan, Septiarini, \&Filianti, Analysis of the factors that influence.....

Sutrisno, M. (2018). Factors determinant of bank capital buffer: empirical study on Islamic rural banking in Indonesia. 15th International Symposium on Management (INSYMA 2018).

Umam, K. (2013). Islamic banking management. CV Loyal Library.

Van Greuning, H., \& Iqbal, Z. (2007). Risk analysis for Islamic banks. The world bank.

Williams, H. T. (2011). Determinants of capital adequacy in the Banking Sub-Sector of the Nigeria Economy: Efficacy of Camels.(A Model Specification with Co-Integration Analysis). International Journal of Academic Research in Business and Social Sciences, 1(3), 233. doi:10.6007/ijarbss.v1i2.36

$\mathrm{Xu}, \mathrm{L}$. , Lee, S.-C., \& Fu, Y. (2015). Impacts of capital regulation and market discipline on capital ratio selection: evidence from China. International Journal of Managerial Finance. doi:10.1108/ijmf-02-2014-0021

Zhu, C., \& Chen, L. (2016). An empirical study on the capital buffer of rural commercial banks in China. Journal of Finance and Economics, 4(3), 97-102. 